\title{
SVEUČILIŠNO OBRAZOVANJE INFORMACIJSKIH STRUČNJAKA: IZAZOVI I MOGUĆI ISKORACI
}

\author{
Dr. sc. Tatjana Aparac-Jelušić, red. prof. u miru / Retired Professor \\ Hrvatska / Croatia \\ aparact@gmail.com
}

\begin{abstract}
Sažetak
Slijedom promjena u području sveučilišnog obrazovanja i niza novih zadaća suvremenih informacijskih ustanova u ovom se radu promišljaju mogući iskoraci prema sustavnom sveučilišnom obrazovanju i stalnom stručnom usavršavanju informacijskih stručnjaka. Neosporno je da je moguće uspoređivati i pronalaziti zajedničke karakteristike obrazovnih programa u području informacijske znanosti, bibliotečne znanosti, bibliotečne i informacijske znanost te programa koje nude tzv. i-schools. Uz to niz je novih ponuditelja obrazovnih programa za upravljanje ogromnim količinama podataka, ekonomiju informacija, digitalne biblioteke, i drugih u kojima sadržaji iz bibliotekarstva (na primjer, organizacija informacija, pretraživanje informacija, informacijsko ponašanje, informacijska pismenost) mogu imati bitno značajniju ulogu. Cilj rada je ukazati na trendove u europskom sveučilišnom prostoru s aspekta obrazovanja bibliotekara $i$ drugih informacijskih stručnjaka te potaknuti na iznalaženje optimalnih rješenja unutar lokalnih, bosanskohercegovačkih okolnosti. Namjera nam je ukazati na potrebu sustavnog promišljanja i djelovanja koje bi uvažavalo tradicionalno shvaćene kompetencije i kritički sagledalo nove mogućnosti s ciljem osmišljavanja atraktivnih i održivih sveučilišnih programa i programa kojima se stečene kompetencije nadograđuju novima. Ti programi trebaju biti dovoljno fleksibilni da odgovore na potrebe novih izazova poput, na primjer, upravljanja novom Univerzitetskom bibliotekom. Temeljem iskustva iz nedavno završenog Erasmus + projekta EINFOSE, nastojimo izdvojiti ključna pitanja za buduće rasprave i odluke.
\end{abstract}

Ključne riječi: sveučilišno obrazovanje, informacijski stručnjaci, bibliotečna znanost, informacijska znanost, Erasmus + projekt EINFOSE

\section{Uvod}

Stručno osoblje jedan je od temelja informacijske infrastrukture, pa valja sustavno isticati da je usporedno $\mathrm{s}$ razvojem informacijsko-telekomunikacijskih tehnologija (IKT) i nacionalne informacijske infrastrukture potrebno razvijati i obrazovne programe za informacijske stručnjake, jer svaki pokušaj razvoja i primjene novih tehnologija izravno je ovisan o osobama koje ju stvaraju ali i znalački koriste. U digitalnom okruženju koje se neprestano i silovito razvija, sveučilišta bi trebala posvetiti veću pažnju obrazovanju unutar sektora informacijskih djelatnosti, osobito informacijskoj i medijskoj pismenosti općenito, a posebno načinu stjecanja znanja i vještina za obradu i pretraživanje informacija, informacijskom prosvjećivanju te skrbi za očuvanje i uporabu analognih i digitalnih informacija i zbirki.
Inozemna iskustva kazuju da se od ranih 1990-ih godina milijuni dolara investiraju u istraživanja o digitalnim bibliotekama, uključujući i načine na koje ti novi pojavni oblici mogu podupirati kulturu, znanost, obrazovanje i gospodarstvo, ali da ulaganja u obrazovanje onih koji u tim novim bibliotekama nude informacijske $\mathrm{i}$ ine usluge daleko zaostaju (usp. Pomerantz et al. 2009, 1).

Obrazovni programi izravno su povezani s tumačenjima koncepta o biblioteci i drugim informacijskim ustanovama u digitalnome dobu, odnosno njihovim zadaćama u i za društvo koje prolazi kroz velike i značajne mijene. Niz je filozofa, sociologa, psihologa $\mathrm{i}$ informacijskih stručnjaka koji se zanimaju za društvene promjene što izrastaju kao posljedica pojave, uporabe i razvoja novih tehnologija te ukazuju na promjenjivost informacijskog okruženja, kao i na prirodu vještina koje današnji informacijski 
stručnjaci trebaju posjedovati (usp. Aparac-Jelušić 2016).

Nakon gotovo dva desetljeća od potpisivanja Bolonjske deklaracije i nastojanja da se europski sveučilišni sustavi osuvremene $i$ učine kompetitivnima u odnosu na rastuće utjecaje i kvalitetu izvaneuropskih sveučilišta, zamjetni su pomaci, ali i problemi koji otežavaju provedbe planova za modernizaciju sveučilišnog obrazovanja. Ta se tvrdnja odnosi i na sveučilišni prostor obrazovanja informacijskih stručnjaka: bibliotekara, arhivista, dokumentalista i drugih. Sve je više onih koji zagovaraju tezu da se ne trebaju (i ne smiju) olako napustiti pojedina baštinjena obilježja bibliotekarstva, arhivistike i dokumentalistike (usp. na primjer, Buckland 2003; Audunson 2005; Kajber 2018). Dapače, iskustva s internetskim "gigantima" koji nude neprovjerene informacije na internetu i društvenim mrežama, govore u prilog potrebi da informacijske ustanove snažnije iskorače u javnost, dokazujući da mogu biti središnji oslonac onima koji razvijaju digitalne službe i usluge kako bi uspostavili distribuirane informacijske i komunikacijske prostore, uključujući i uvažavanje znanja informacijskih stručnjaka koja su nezaobilazna za razvoj umjetne inteligencije (usp. Bates 2019).

U ovome radu polazimo od uvjerenja da valja vjerovati u to da će tradicionalne vrijednosti moći preživjeti i biti upotrebljive te da je društvena uloga biblioteka i drugih informacijskih ustanova važna u svijetu koji se tako brzo mijenja. Na tom tragu sagledavamo potrebu da kreatori obrazovnih programa za informacijske stručnjake prihvate izazove brzih i dubokih tehnoloških promjena, promišljajući o tome koja su to temeljna znanja i vještine studentima korisna te kritički sagledavajući ona koja su tehnološki "trendovska", koja se brzo zamjenjuju drugim rješenjima ili padaju u zaborav nakon kratkog vremena.

\section{Europski sveučilišni prostor i nove IKT}

Kao što je opće poznato i u brojnim radovima dokumentirano (usp. na primjer, Tammaro 2011; Kampylis et al. 2012; Johnson et al. 2015, García Marco 2013; Myburgh, Tammaro 2013; Sursock 2015; Van Rij 2015; Virkus 2015; Kajberg 2018), protekla dva desetljeća sveučilišno je obrazovanje u Europi prolazilo kroz duboke promjene, utemeljene na viziji objedinjenog obrazovnog prostora, jačanja uloge sveučilišta u javnom životu i gospodarstvu.

Strategija Europa 2020 naglasila je potrebu temeljite preobrazbe obrazovanja i osposobljavanja za nove vještine i kompetencije kako bi Europa ostala konkurentna, prevladala ekonomsku krizu i iskoristila nove mogućnosti (usp. Aparac-Jelušić 2017). Zbog toga se, vodeći računa o europskom obrazovnom prostoru, široko raspravlja o tome na koji način obrazovati informacijske stručnjake različitih profila, što potiče i motivira osmišljavanje i ponudu inovativnih pristupa i novih metoda poučavanja, te kako najbolje iskoristiti potencijale zajedničkih programa (joint programs).

Za obrazovanje informacijskih stručnjaka tehnološki napredak jedan je od najvažnijih pokretača promjena. Horizon Report o sveučilišnom obrazovanju (New Media Consortium 2014) identificirao je šest izranjajućih tehnologija za koje se očekivalo da bi mogle imati utjecaja na sveučilišno obrazovanje do konca drugog desetljeća 21. stoljeća, poput novog tumačenja koncepta učionice (flipped classroom), poticanja analitičkog učenja, uporabe 3D tiskanja i igara u nastavi, uključivanja kvalificiranih virtualnih pomoćnika, zagovaranja i poticanja učeničke (ali i nastavničke!) inovativnosti (na primjer, Bring Your Own Device - BYOD), korištenja adaptivnih tehnologija i slično. Dakako, sve te tehnologije povezane su s ključnim trendovima u društvenom okruženju, poput rastuće važnosti i sve masovnijeg korištenja društvenih medija, integracije online, hibridnog i kolaborativnog učenja, porasta učenja temeljenog na podacima, pomaka od studenta kao korisnika prema studentu stvaraocu, daljnjeg razvoja online učenja, jačeg usmjerenja ka mjerenju učenja, širenja OER-a (Open Educational Resources) i MOOCa (Massive Online Courses), razvoja naprednih kulturâ, promjena i inovacija te rastuće međuinstitucijske suradnje (usp. Johnson et al. 2015; Aparac-Jelušić 2016). Pojedini aspekti tradicionalnih obrazovnih modela sve se teže nose s rastućim brojem online kolegija, OER-a i MOOC-a, a konkurencija novih ponuđača obrazovnih programa uočljiv je trend o čijim se ishodima i vrijednostima tek naslućuje, ali nedovoljno istražuje (usp. van Rij 2015, 33). No, jedna je važna posljedica navedenih trendova: izazvali su sveučilišta na to da se sve više usmjeruju na pitanja pedagogije i svrsishodnog korištenja IKT u procesima podučavanja i učenja (usp. Virkus 2008; Rajabi, Virkus 2013) te da jačaju suradnju i potiču mobilnost kako studenata tako i nastavnika.

O tim promjenama u sveučilišnom obrazovnom prostoru pisali su i informacijski stručnjaci (usp. na primjer, Johnson et al. 2015; Virkus 2015; AparacJelušić 2016, 5), a cijeli broj časopisa Education for Information (2019) posvećen je temama koje su vezane uz inovativne pristupe obrazovanju u području bibliotečne i informacijske znanosti (BIZ). U tom su broju, između ostalih, objavljeni prilozi o novim didaktičkim pristupima i metodama podučavanja u području BIZ-a, utjecaju trendova na oblikovanje kurikuluma, osobito sa stajališta stvaranja i korištenja MOOC-a, dosadašnjim rezultatima provedenih istraživanja vezano uz iskustva s novim metodama, osobito igara, kombiniranih učionica, tzv. Open Badges i slično, na studentsku populaciju. 
Svakako treba imati na umu da se navedeni i drugi trendovi prihvaćaju s različitim vremenskim odmacima. Horizon Report (New Media Consortium 2014) ukazao je na tri vremenske kategorije: brze trendove koji svoj učinak postižu u godinu do dvije te na dvije kategorije sporijih trendova (srednje dugi i dugotrajni) koji svoj utjecaj ostvaruju unutar tri do pet godina ili kasnije. Tomu dodajmo da se vrijeme upoznavanja s novim trendovima razlikuje od sredine do sredine, pri čemu se razvijene zemlje svrstavaju među one koje predvode, a zemlje u razvoju u onu skupinu koja uglavnom s odmakom od nekoliko godina saznaje o novostima te ih naposljetku počinje prihvaćati. Sporije vrijeme prihvaćanja ima $\mathrm{i}$ jednu korisnu prednost, a to je da često koincidira $\mathrm{s}$ kritičkim refleksijama koje mogu dovesti do realnijeg sagledavanja doprinosa pojedinog trenda obrazovanju ili pak otklona od njegove daljnje primjene.

U pogledu strateških planova prekretnicu u razvoju sveučilišnog obrazovanja u Europi izazvao je "bolonjski proces" kojemu se, nakon dvadesetak godina, upućuju i pohvale i kritike. Kako je u fokusu zanimanja pokretača "bolonjskog procesa" ležala problematika vrijednosti koordiniranih reformi, kompatibilnih edukativnih sustava i zajedničkih aktivnosti, zabilježeno je mnogo pokušaja europskih sveučilišta da moderniziraju obrazovne programe u području informacijskih znanosti. Međutim, zamjetno je da nisu u svim zemljama jednako poštivane preporuke o tri razine sveučilišnog obrazovanja $(3+2+3)$, da su pojedini programi promijenjeni formalno, a ne sadržajno, da nedostaje nastavno osoblje, osobito s kompetencijama iz novih područja koja se uključuju u postojeće programe (na primjer, za digitalnu skrb, za obradu velikog broja podataka, za upravljanje bazama podataka), da su izborni predmeti u sklopu pojedinog studijskog programa šaroliki i brojni, umjesto da se nude na razini cijeloga sveučilišta, kao i na to da se zdušno zagovaraju STEM područja, ali bez njihova dovođenja u vezu s temeljnim znanjima i vještinama iz društvenih $\mathrm{i}$ humanističkih znanosti neophodnima za opće obrazovanje i kritičko razmišljanje.

\section{Obrazovanje informacijskih stručnjaka u Europi}

Koncem prvog desetljeća 21. stoljeća L. Kajberg (Kajberg 2007, 69) opisao je prostor obrazovanja informacijskih stručnjaka u Europi kao vrlo složen, ukazavši pritom na mnoštvo kultura i jezika, mozaika nacionalnih tradicija, kao i na različite obrazovne tradicije i poglede koji su rezultirali različitim pristupima, modelima, strukturama programa, obrazovnim razinama, nestalnom stopom zapošljivosti, promjenjivim sadržajima kurikuluma i opsegom predmeta, načinima poučavanja i ocjenjivanja itd.
Svjesni tih razlika, obrazovni stručnjaci u području BIZ-a s većim ili manjim intenzitetom otvaraju rasprave i nastoje postići dogovore oko usklađivanja sadržaja, osobito temeljnih predmeta, i ishoda učenja. Napori su usmjereni i prema istraživanju načina kako da se organiziraju zajednički programi, čemu potporu pruža i Europska Unija kroz programe financiranja združenih studija na diplomskoj i poslijediplomskoj razini. Pritom su do izražaja došle razlike u pristupima obrazovanju bibliotekara, kasnije i drugih informacijskih stručnjaka, koje je u pojedinim sredinama bilo suočeno s dilemom da li obrazovati za struku ili se prikloniti sveučilišnom obrazovanju. Nastojanje da se uspostavi skladan odnos između teorije i prakse bilo je jedno od mnogih pitanja pozicioniranja obrazovnih ustanova unutar akademske zajednice. Čak i nakon što je uspostavljeno sveučilišno obrazovanje bibliotekara, a zatim $\mathrm{i}$ arhivista, dokumentalista $\mathrm{i}$ drugih informacijskih stručnjaka, u nekim se zemljama za sveučilišne nastavnike nije tražio doktorat znanosti (usp. na primjer, Veliku Britaniju do gotovo konca 20. stoljeća), dok je u nekim zemljama, na primjer u zemljama Istočne Europe, pristup bio drugačiji, pa je uspostava ili dokidanje sveučilišnog obrazovanja izravno ovisila o broju nastavnika u odgovarajućim akademskim zvanjima ili pak političkim, a ne stručno utemeljenim odlukama. ${ }^{1}$ Drugi se problem odnosi na dvostruku mogućnost ulaska u struku. Naime, u nekim sredinama i nadalje prevladava mišljenje da su stručni ispiti dostatna razina kako za ulazak u struku, tako i za djelovanje tijekom radnoga vijeka, ili su pak formalno postojala (postoje) dva načina ulaska u struku (sveučilišno obrazovanje i stručni ispit), što se počelo mijenjati tek 1990-ih godina prošlog stoljeća (usp. na primjer promjene u Hrvatskoj iz 1997. kada je Zakon o knjižnicama dokinuo institut stručnih ispita kao alternativu sveučilišnom obrazovanju, a zadržao ga kao temelj za stjecanje stručnog zvanja nakon završenog studija). Tomu valja dodati i sadržaje takvih programa koji se ne mijenjaju i po desetak i više godina te tako propuštaju ugraditi nove sadržaje, čime umanjuju kompetentnost onih koji su ih položili.

Promjene u okruženju i nadalje su snažne, često nepredvidive. Sveučilišta na kojima se nude obrazovni programi iz informacijskih znanosti uglav-

\footnotetext{
1 U Poljskoj je, na primjer, nedavno dokinut uvjet da se u bibliotekama zapošljavaju osobe sa sveučilišnim obrazovanjem iz bibliotekarstva uz argumentaciju da biblioteke trebaju informacijske stručnjake. Slijedom te odluke, Sveučilište u Łódźu, nakon provedenog istraživanja o traženim zanimanjima, odlučilo se za nov studij: Informatologija s engleskim poslovnim jezikom, na Odsjeku za informatologiju i bibliologiju, stavljajući naglasak na razvoj i pretraživanje informacijskih izvora, obradu informacija, selekciju, dokumentiranje i publiciranje informacija, uključujući infografiku (usp. Antczak i Gruszka, 2018).
} 
nom dopuštaju, odnosno očekuju od odjela/odsjeka da sami predlažu nove ili modificirane kurikulume, povezivanje sa srodnim odjelima/odsjecima slijedom vizije samih nastavničkih timova i njihova razumijevanja novih pristupa obrazovanju. Pritom se vizije mogu odnositi na jednu disciplinu ili na više njih, prije svega na one koje mogu pružiti podršku obrazovanju informacijskih stručnjaka iz perspektive temeljnih predmeta i njihovih osuvremenjenih sadržaja te uvrštavanja novih tema i načina podučavanja. Najčešće se usuglašavanje postiže oko obrazovanja za djelovanje unutar baštinskog sektora, ${ }^{2}$ digitalne humanistike ili novih tehnologija. Nove su tehnologije posebno istaknute na tzv. i-schools. ${ }^{3}$ Ti novi informacijski stručnjaci, očekuje se, neće djelovati samo kao bibliotekari, arhivisti ili dokumentalisti, osposobljeni da unutar pojedine informacijske / baštinske ustanove postave korisnike u središte posredovanja informacija, već i da budu u stanju timski raditi kako bi dizajnirali i održavali informacijsku infrastrukturu, analizirali i administrirali podatke, razvijali web, ontologije, strategije za društvene medije, provjeravali korištenje, štitili podatke itd. (usp. Aparac-Jelušić 2016).

Između 2005. godine, kada je provedeno istraživanje u sklopu europskog projekta "Razvoj kurikuluma u BIZ području" (usp. Borup Larsen 2005), prošlo je deset godina do opsegom značajnog, a rezultatima zanimljivog istraživanja koje je proveo A. Borrego (2015). Prema njegovim nalazima, u Europi je 2014. djelovalo 220 institucija koje su nudile programe u području BIZ-a, preciznije, programe vezane uz digitalne knjižnice, u 26 zemalja.

Zanimljivo je i istraživanje Audunsona i Shuvae (2016) koje se također bavilo obrazovanjem za digitalne biblioteke u Europi, posebno sadržajem kurikuluma, te je nastojalo istražiti buduće pravce razvoja u području obrazovanja za BIZ. Na odaslani upitnik autori su dobili odgovore iz 54 obrazovne ustanove iz 27 europskih zemalja koje nude programe iz bibliotekarstva i drugih informacijskih znanosti. Na osnovi analize prikupljenih odgovora, zaključili su da je većina obrazovnih programa sa-

\footnotetext{
2 U Hrvatskoj, zajednički diplomski program između između Sveučilišta u Osijeku i Sveučilišta u Zadru akreditiran je 2007. godine. Njegov naslov "Pisana baština u digitalnom okruženju" govori o namjeri da se objedine informacijske, računalne i humanističke discipline kako bi se studenti obrazovali za planiranje, provođenje i vrednovanje programa digitalizacije te za upravljanje digitalnim zbirkama i uslugama.

3 I-schools pokret, kako se često naziva ta inicijativa, okuplja one sveučilišne obrazovne odjele/odsjeke koji su u svojim programima istaknuli informacijske predmete i sadržaje. Inicijativa je pokrenuta 2002. godine, da bi 2005. bila službeno prijavljena kao i-schools organizacija (up. https://ischools. org). Danas broji stotinjak članica. Na području bivše Jugoslavije i šire regije, jedino je dosad u članstvo primljen Odsjek za informacijske znanosti pri Filozofskom fakultetu Sveučilišta u Osijeku.
}

držaje iz digitalnog bibliotekarstva već integrirala u svoje redovne preddiplomske i diplomske studije te da je obrazovanje za nove profile bibliotekara i drugih informacijskih stručnjaka pod utjecajem glavnih istraživačkih trendova o digitalnom društvu.

U najnovijem pokušaju Mechede, Ortiz-Repiso i Kluin (2018) predstavili su prve analize istraživanja koje su proveli sa svrhom izrade interaktivne obrazovne mape u području BIZ-a u Europi: u 51 europskoj zemlji (uključujući Izrael) u njih 32 nude se određeni oblici obrazovanja iz BIZ-a na 140 ustanova. Brojčano iskazano, radi se o 157 preddiplomskih studija, 150 diplomskih i 41 doktorskom studiju. Među zemljama s najviše programa su Francuska (17), Španjolska (16) i Njemačka (14). Razlike u pristupima i dalje su zamjetne. Istraživanje je pokazalo da je $40 \%$ studija fokusirano je na BIZ (u užem smislu, bibliotekarstvo sa značajnijim usmjerenjem prema IKT-u). U Švedskoj, Italiji i Belgiji, gotovo svi ponuđeni programi su povezani s humanističkim studijima, usmjerenost prema informacijskom menadžmentu i upravljanju znanjem zamjetna je kod Portugala i Turske, a u Nizozemskoj su posebno naglašene medijske studije. Zanimljivo je da su veze prema arhivistici zabilježene samo u Češkoj i Norveškoj. U odnosu na kompjutorske znanosti izdvojena je Austrija, a među zemljama u kojim programi gotovo podjednako uključuju različite tematske cjeline ističe se Finska, koja povezuje komunikologiju, društvene znanosti i BIZ. Potrebno je na ovome mjestu dodati da provedeno istraživanje, nažalost, nije uključilo zemlje bivše Jugoslavije s njihovim specifičnostima, što zasigurno zaslužuju veću pozornost.

Značajno je također istraživanje koje je inicirala IFLA (Južnič et al. 2018) koje je obuhvatilo cijeli svijet, ne samo Europu, s usmjerenošću prema kurikulumima i kompetencijama studenata koji se obrazuju prvenstveno za bibliotečno područje. Rezultati su pridonijeli raspravama o stupnju zadovoljstva obrazovnih ustanova u području BIZ-a u odnosu na ishode učenja na koje poslodavci učestalo imaju primjedbe, smatrajući da ti programi ne prate dovoljno trendove i potrebe za budućim profesionalcima.

Rasprave o razvoju novih programa te međuinstitutskoj suradnji i internacionalizaciji usmjerile su se i na ulogu profesionalnih udruženja i mreža, europskih projekata i oblika potpore, zajedničke međunarodne programe ili kolegije, uključujući kolegije na bazi IKT-a i zajedničke doktorske programe (usp. preglede koje donosi Virkus 2007 i 2008; Kajberg 2018).

Nije na odmet skrenuti pažnju na upozorenja onih autora koji razmišljaju o bliskoj budućnosti i pritiscima tržišta rada. Tako Eisenberg and Fullerton (2012, 5), izlažući svoju viziju sveučilišnog obrazovanja za sljedećih 50 godina, ističu da je središ- 
nja točka interesa pojedini student te da se očekuje decentralizirano obrazovanje s nizom različitih stupnjeva podučavanja i stjecanja diploma. Njihova vizija potiče na razmišljanje o promijenjenoj ulozi sveučilišta danas, ali i sutra. Sveučilišta su suočena s trendom da nisu više jedina koja nadziru sredstva i ciljeve obrazovanja. Javljaju se konkurenti koji omogućuju stjecanje znanja i vještina i na različite druge načine. Sveučilišta nesumnjivo trebaju uložiti velik napor u jačanje svoje autonomije u odnosu na akademska pitanja, nuditi kvalitetne kompetitivne programe nasuprot kratkim tečajevima koji se organiziraju kako bi se popunile praznine u obrazovanju iz informacijskih vještina potrebnih na rastućem tržištu, te jačati međunarodne veze uključujući mobilnost studenata i nastavnika.

O mogućim oblicima internacionalizacije programa i jačanja međuinstitucionalne suradnje u području obrazovanja informacijskih stručnjaka raspravljalo se u okviru projekta EINFOSE (European Information Science Education: Encouraging Mobility and Learning Outcomes Harmonization - Europski pristupi obrazovanju u području informacijske znanosti: Ohrabrivanje mobilnosti i usklađivanje ishoda učenja) u vremenu od 2016. do 2018. Cilj je projekta bio iznaći načine da se prevladaju razlike koje su uočene prilikom upisa na diplomske studije iz informacijskih znanosti i da se pokušaju uskladiti ishodi učenja na osam europskih sveučilišta, partnerskih ustanova. $^{4}$

Naime, na partnerskim se sveučilištima poučava u rasponu od usmjerenosti ka informacijskoj znanosti, poslovnom menadžementu, kompjutorskoj ili pak bibliotečnoj i informacijskoj znanosti, a na diplomski studij se upisuju ili samo studenti koji su stekli bakalaurat iz jednog od navedenih programa ili pak studenti koji su bakalaurat stekli na bilo kojem drugom preddiplomskom studiju. Praksa je, na primjer, na hrvatskim sveučilištima, što se tiče studija iz informacijskih znanosti (koji obuhvaća bibliotekarstvo, arhivistiku, muzeologiju, informatologiju i srodne informacijske i komunikacijske discipline), da studenti redom nastavljaju isti studij na diplomskoj razini, pa se osjeća potreba za privlačenjem studenata iz drugih disciplina nastojeći ih zainteresirati za informacijske sadržaje savladavanjem kojih bi stjecali znanja i vještine organizacije i upravljanja informacijskim sustavima u području koje najbolje poznaju. Također, jedna od radnih pretpostavki bila je da su očekivani ishodi učenja vrlo raznoliki te da programom predviđeni ECTS-i

\footnotetext{
4 To su bila sveučilišta u Barceloni (Španjolska), Boråsu (Švedska), Grazu (Austrija), Ankari (Turska), Hildesheimu (Njemačka), Ljubljani (Slovenija), Pisi (Italija) i Osijeku (Hrvatska). Tim iz Osijeka bio je nositelj projekta, a njegova voditeljica T. Aparac-Jelušić.
}

(European Credit Transfer System) otežavaju postupke priznavanja diploma stečenih tijekom mobilnosti. Stoga se projektom nastojalo istražiti kako se uočene razlike i prepreke mogu otkloniti ili bar smanjiti (usp. Aparac-Jelušić et al. 2018).

Tokom rada na projektu konzultiran je Europski kvalifikacijski okvir (European Qualifications Framework - EQF) i njegove nacionalne varijante tamo gdje su odobrene. U centru samog EQF-a je osam referentnih razina koje opisuju ishode učenja za svaku pojedinu obrazovnu razinu, podijeljene u "znanje", "vještine" i "odgovornost i autonomnost" (usp. Descriptors 2018). Osim navedenog, proučen je i dokument poznat pod nazivom ESCO (European Skills, Competencies and Occupations). Radi se o klasifikacijskom sustavu koji pokriva vještine, kompetencije, kvalifikacije i zanimanja, izrađenom s ciljem da europsko tržište rada postane djelotvornije i učinkovitije. Za područje BIZ-a od posebne je važnosti mogućnost korištenja znanja i vještina stečenih tokom sveučilišnog obrazovanja (usp. ESCO 2018).

Dakako, posebna je pažnja posvećena preporukama iz stručnih udruga, poput IFLA-e, ALA-e, ALIAe, SLA (navedeno u Literaturi). Kako je istaknuto u završnom EINFOSE dokumentu Preporuke za uvjete upisa na diplomske studije i za usklađivanje ishoda učenja (Policy Recommendation for the Entry Requirements and Learning Outcomes Harmonization), ${ }^{5}$ obrazovanje informacijskih stručnjaka treba uključiti uz sektorska i transverzalna i međusektorska znanja, vještine i kompetencije (usp. Vilar et al. 2018). EINFOSE Preporuke organizirane su na nekoliko razina za različite grupe, ustanove ili tijela: EINFOSE partnere, sveučilišne ustanove u području BIZ i informacijske znanosti, EU programske koordinatore, donositelje odluka, potencijalne poslodavce i profesionalne udruge.

Partneri su se dogovorili da buduće promjene obrazovnih programa trebaju voditi računa o studentima, nastavnicima, kurikulumu i načinima podučavanja kada odlučuju o tome što je iz postojećih programa vrijedno zadržati, što treba izostaviti, a što prilagoditi ili uvesti kao novo. Uz navedene Preporuke, EINFOSE projekt ponudio je svoju platformu za podučavanje i učenje, četiri predmeta dostupna kao OER-i (na jezicima partnera), evaluacijski okvir i pedagoški okvir. ${ }^{6}$

\footnotetext{
5 Nacrt tog dokumenta bio je ponuđen za javnu raspravu na završnoj EINFOSE konferenciji u Pisi, u septembru 2018. Više o samoj konferenciji na http://feis2018.di.unipi.it, a o navedenom dokumentu na http://einfose.ffos.hr/intellectualoutputs/05.

6 Svi su rezultati projekta dostupni na http://einfose.ffos.hr/ intellectual-outputs.
} 


\section{Zaključna razmišljanja}

U ovome smo radu pošli od toga da su razlozi za uvođenje promjena i inovacija u evropskom sveučilišnom prostoru bili povezani s ekonomskom krizom, nekompetitivnošću u odnosu na druge sredine, nedovoljnim izvorima financiranja, "okoštalim" upravljačkim strukturama i neravnomjernom korištenju novih tehnologija. Od europskih se sveučilišta, od uvođenja "bolonjskog procesa", očekivalo da značajno iskorače prema modernizaciji i internacionalizaciji. Te promjene nisu zaobišle ni obrazovanje informacijskih stručnjaka koje je uza sve navedene izazove, suočeno i s krizom disciplinarnog i profesionalnog identiteta. Naime, već je W. L. Saunders (1974) govorio o "izuzetno varljivoj i škakljivoj prirodi cjelovitog koncepta informacijske znanosti”, a J. H. Shera (1973) upozoravao na to da informacijskoj znanosti predstoji težak zadatak da se dokaže kao disciplina s obzirom na to da je

u najvećoj mjeri još uvijek aglomeracija tehnologija preuzetih iz drugih područja, te da ju obilježava duboka kriza identiteta budući da "(...) ni sama ne zna točno što je ili kamo ide i da ne može jasno odrediti pripada li školi bibliotečne znanosti, tehničkih znanosti [ili] menadžmenta" (...).

Pokušaji da se rješenje problema zbrke nastale oko različitih interpretacija pojma informacijska znanost iznađe u korištenju tzv. "snage plurala" - informacijske znanosti, okupljene ispod zajedničkog kišobrana povezanih disciplina i polja istraživanja sa zajedničkim obilježjima, odražavaju se i na obrazovne programe, osobito u manjim sredinama u kojima brzo dođe do zasićenja "tržišta" pa je potrebno predviđati nove poslovne sredine za informacijske stručnjake koji će se lako uklapati u različite tipove informacijskih ustanova, kompjutorske tvrtke, ustanove s velikim brojem podataka koje treba organizirati i slično.

Ne treba zaboraviti da su upravo mnogi europski odjeli/odsjeci u području BIZ-a stekli ugled unutar svojih sveučilišta na osnovi vlastitih inicijativa vezano uz tehnološke inovacije u nastavi i spremnosti da prihvaćaju promjene. Postali su vodeći u uvođenju online kolegija, $u$ integraciji tehnologije i obrazovanja, interdisciplinarnoj i međunarodnoj suradnji (primjeri za to su i sva tri hrvatska sveučilišna odjela/odsjeka koja su predvodila procese e-učenja, informacijskog opismenjavanja i slično).

Na tragu Audunsonovih razmišljanja (2005) smatramo da je nužno prepustiti svakoj akademskoj ustanovi da razmisli, o svom putu "u budućnost" propitkujući pritom kako može postići ravnotežu između neovisnosti o praksi i povezanosti s praksom, kako može produbiti profesionalni pristup: od multidisciplinarnosti i interdisciplinarnosti do ja- sne ideje o posebnostima i specijalnostima unutar širokog područja informacijskih znanosti. Važnim se čini i izazov iznalaženja rješenja za obrazovanje informacijskih stručnjaka unutar malih zemalja, a da se ne upadne u zamku obrazovanja za pojedinu instituciju, odnosno djelatnost te iznalaženje ravnoteže između prihvaćanja izazova brzih i dubokih tehnoloških promjena i opasnosti da se studentima isporučuju efemerna tehnološka znanja. U odnosu na bosansko-hercegovačku situaciju koju obilježuje relativno duga tradicija akademske izobrazbe $u$ području BIZ-a s Odsjekom za komparativnu književnost i bibliotekarstvo kao značajnim rasadnikom školovanih bibliotekara, poseban je izazov nova zgrada Univerzitetske biblioteke u kojoj se predviđaju radna mjesta za preko sto zaposlenih, među kojima je za stručne, razvojne i koordinativne poslove predviđeno oko $60-70 \%$ akademski obrazovanih stručnjaka. Njihova je važna uloga ne samo u pripremi selidbe u novu zgradu već i u osmišljavanju inovativnih usluga, upravljanju bibliotečnim sistemom na Univerzitetu koji ima niz fizički izdvojenih biblioteka, zaštiti i brizi za pisanu kulturnu baštinu, programima predstavljanja Univerziteta kulturnoj i znanstvenoj javnosti kao i zainteresiranim građanima i sličnim iskoracima.

Croninovo upozorenje (Cronin 1998) "(A)ko je BIZ program uspješan netko drugi će ga preuzeti pa će kao takav nestati, ako BIZ program nije uspješan, bit će ukinut" - ne ostavlja mjesta za treći pravac. Uspješni programi, naime, mogu opstati uz mudro vođenje kadrovske i razvojne politike unatoč očitim nepovoljnim okolnostima, zatvaranju bibliotečnih i informacijskih odjela, njihovu spajanju s drugim, za sveučilišne uprave financijski isplativijim programima, restrukturiranju i preuzimanju drugih (popularnijih) naziva (usp. i Aparac-Jelušić 2016).

Profesija informacijskog stručnjaka i sveučilišne sredine u kojima se oni obrazuju kročile su u razdoblje rastućeg skepticizma u odnosu na budućnost koja je prepuna izazova. Štoviše, očigledno je da se sveučilišta trebaju odmaknuti od pretpostavki i ograničenja temeljenih na "lošim" iskustvima i iskoraknuti prema istraživanjima podržanim konceptima koji će uvažavati različite perspektive i studenata i budućih poslodavaca.

Valja vjerovati da će nastavnici u području BIZ-a, uključujući i brojem skroman ali znanstveno-nastavno respektabilan tim na sarajevskom Odsjeku, ozbiljno pristupiti novim izazovima, kao što su to činili svaki put kad je trebalo prihvatiti nove tehnologije i nove oblike komunikacije u društvu te da će sustavno propitivati ishode programa koje nude, mogućnosti osuvremenjivanja programa i na tom putu jačanja suradnje s drugim obrazovnim ustanovama i kolegama. Također, čini se važnim pratiti potrebe za novim informacijskim profilima koji ne- 
dostaju, osobito u odnosu na očekivane promjene koje će donijeti nova zgrada Univerzitetske biblioteke, te oblikovati programe koji su fleksibilni i atraktivni za nove generacije studenata.

\section{Literatura}

- ALA. 2009. "Ala's Core competences of Librarianship". https://lianza.org.nz/professionalregistration/bodies-knowledge.

- ALIA. 2014. "The library and information sector: Core knowledge, skills and attributes". https://www. alia.org.au/about-alia/policies-standards-and-guidelines/library-andinformation-sector-core-knowledge-skills-and-attributes.

- Antczak, M., i Z. Gruszka. (2018). "Information Science in Poland on the example of the University of Lødz" U The Future of Education in Information Science. Proceedings from FEIS - International EINFOSE Symposium 10-11 September 2018 Pisa, Italy, uredili T. Aparac-Jelušić, V. Casarosa i E. Macevičiūté, 199-205. Osijek: Filozofski fakultet. http://einfose.ffos.hr/feis-2018/proceedings

- Aparac-Jelušić, T. 2016. "Obrazovanje za digitalne knjižnice: pogled iz Europe" Libellarium 9(2). http://libellarium.org/index.php/libellarium/article/ view/289/427.

- Aparac-Jelušić, T. 2017. Digital Libraries for Cultural Heritage: Development, Outcomes, and Challenges from European Perspectives. Morgan and Claypool. Synthesis lectures on information concepts, retrieval, and services; 58 (Series Editor: Gary Marchionini).

- Aparac-Jelušić, T., S. Faletar Tanacković, i K. Petr Balog. 2018. "Approach to harmonization of entry requirements for graduate program in information science at Eurepean higher institutions: EINFOSE project" U Proceedings of the Association for Library and Information Science Education Annual Project: ALISE 2018, uredili P. Wang, A. Green i S. Assefa, 6-10. Seattle: The Association for Library and Information Science Education (ALISE).

- Aparac-Jelušić, T., i Kurbanoglu, S. 2019. Education for Information. Special issue. IOS Press, 1.

- Audunson, R. 2005. "Editorial: LIS and the creation of a European educational space" Journal of Librarianship and Information Science 37: 171-174.

- Audunson, R. A., i N. Z. Shuva. 2016. "Digital library education in Europe: A survey" SAGE Open, January-March: 1-17. https://us.sagepub.com/en-us/nam/ open-access-at-sage. Datum pristupa: 4. 3. 2016.

- Bates, M. E. 2019. “Chancen für Information Professionalsin der Welt Künstlicher Intelligenz. Michael Klems im Intervju mit Mary Ellen Bates" Open Password. Montag, den 9. September 2019.
- Borrego, Á. 2015. "Library and Information Education in Europe: an overview" BiD: textos universitaris de biblioteconomia i documentació 35. http:// bid.ub.edu/pdf/35/en/borrego.pdf. Datum pristupa: 6. 5. 2016.

- Borup Larsen, J. 2005. "A Survey of Library and Information Sience schools in Europe" U European Curriculum Reflections on Library and Information Science Education, uredili L. Löring i L. Kajberg, 233-241. Copenhagen: Royal School of Library and Information Science.

- CILIP. 2013. "Professional knowledge and skills base". https://www.cilip.org.uk/page/PKSB.

- Cronin, B. 1998. "Information professionals in the Digital Age" International Information and Library Review 30: 37-50.

- Descriptors. (2018). "Descriptors defining levels in the European Qualifications Framework (EQF)". https://ec.europa.eu/ploteus/en/content/descriptorspage.

- Eisenberg, M. B., i S. P. Fullerton. 2012. "ED and INFO 2052: Oh, the places you'll go!" U Information professionals 2050: Educational possibilities and pathways, uredili G. Marchionini i B. Moran, 1-17. North Carolina: School of Information and Library Science of University of North Carolina at Chapel Hill. http://sils.unc.edu/sites/default/files/news/Information-Professionals-2050.pdf.

- European Commission. Education and training. http://ec.europa.eu/education/library/policy/modernisation_en.pdf.

- ESCO. Skill reusability level. https://ec.europa.eu/ esco/portal/escopedia/Skill_reusability_level.

- European Qualifications Framework (EQF). http:// www.cedefop.europa.eu/hr/events-andprojects/projects/european-qualifications-framework-eqf.

- García Marco, F.-J. 2013. "Educación y aprendizaje de la información y la documentación: raíces, desafíos y líneas de actuación" El profesional de la información 22(6): 489-504. http://www.elprofesionaldelainformacion.com/contenidos/2013/noviembre/01.pdf.

- IFLA BSLISE Working Group. 2018. Building strong LIS education: A call to global and local action - An IFLA BSLISE Working Group White Paper. Cape Town: University of Cape Town Libraries. doi:http://dx.doi.org/10.15641/0-7992-2542-6; http://openbooks.uct.ac.za/liseducation/index.php/ liseducation/catalog/view/1/1/11- 2 . 
- Johnson, L., S. B. Adams, V. Estrada, i A. Freeman. 2015. NMC Horizon Report: 2015 Higher Education Edition. Austin, Tex.: The New Media Consortium. https://net.educause.edu/ir/library/pdf/HR2015.pdf. Datum pristupa: 6. 5. 2016.

- Južnič, P., F. Renon, i T. Heco. 2018. "Towards building a strong LIS education: Preliminary findings from aninternational environmental scan of LIS education, certification and professional identity (European focus)" U The Future of Education in Information Science. Proceedings from FEIS - International EINFOSE Symposium 10-11 September 2018 Pisa, Italy, uredili T. Aparac-Jelušić, V. Casarosa i E. Macevičiūtè, 112-122. Osijek: Filozofski fakultet. http://einfose.ffos.hr/feis-2018/proceedings

- Kajberg, L. 2007. “The European LIS Curriculum Project: An overview" Journal of Education for Library and Information Science 48(2): 68-81.

- Kajberg, L. 2018. 'Reflections from 'backstage': a still keen LIS observer's look at LIS education and Europe" U The Future of Education in Information Science. Proceedings from FEIS - International EINFOSE Symposium 10-11 September 2018 Pisa, Italy, uredili T. Aparac-Jelušić, V. Casarosa i E. Macevičiūtè, 241-257. Osijek: Filozofski fakultet. http://einfose.ffos.hr/feis-2018/proceedings

- $\quad$ Kampylis, P. G., S. Bocconi, i Y. Punie. 2012. Towards a mapping framework of ICT enabled innovation for learning. European Commission. JRC Scientific and Policy Reports. Luxemburg: Publications Office of the European Union. http://ftp.jrc.es/EURdoc/ JRC72277.pdf. Datum pristupa: 6. 5. 2016.

- $\quad$ Meschede, C., V. Ortiz-Repiso, i M. Kluin. 2018. "Library and Information Science education in Europe: Building an interactive map" U The Future of Education in Information Science. Proceedings from FEIS - International EINFOSE Symposium 10-11 September 2018 Pisa, Italy, uredili T. Aparac-Jelušić, V. Casarosa i E. Macevičiūtè, 217-222. Osijek: Filozofski fakultet. http:/einfose.ffos.hr/feis-2018/ proceedings

- Myburgh, S., i A. M. Tammaro. 2013. Exploring education for digital librarians: Meaning, modes and models. Oxford, UK: Chandos.

- New Media Consortium. 2014. "The NMC Horizon Report: 2014 Higher education edition". http://cdn. nmc.org/media/2014-nmc-horizon-report-he-ENSC.pdf. Datum pristupa: 6. 3. 2016.

- Pomerantz, J., J. Abbas, i J. Mostafa. 2009. “Teaching digital library concepts using digital library applications" International Journal on Digital Libraries 10: 1-13.

- Rajabi, H., i S. Virkus. 2013. "The Potential and readiness of Tallinn university to establish Massive Open Online Courses (MOOCs)" Qualitative and Quantitative Methods in Libraries (QQML)
4: 431-439. http://www.qqml.net/papers/December_2013_Issue/249QQML_Journal_2013_Rajabi Virkus_4_431_439.pdf. Datum pristupa: 6. 4. 2016.

- $\quad$ Saunders, W. L. 1974. "The Nature of Information Science" Information Scientist 8(2): 57-70.

- $\quad$ Shera, J. H. 1973. "Toward a theory of librarianship and information science" U J. H. Shera. Knowing books and men, knowing computers too, 93-100. Littleton, VO: Libraries Unlimited.

- $\quad$ SLA 2016. Competencies for information professionals. https:/web.archive.org/web/20170321172834/ http://www.sla.org:80/aboutsla/competencies/.

- Shera, Jesse H. 1973. "Toward a theory of librarianship and information science" Ci. Inf. 2(2): 8797. http://www.brapci.inf.br/_repositorio/2010/05/ pdf_08a30fc288_0009925.pdf.

- Sursock, A. 2015. Trends 2015: Learning and teaching in European universities. Brusselles: European University Association. http://www.eua.be/ Libraries/Publications_homepage_list/EUA_Trends_2015_web.sflb.ashx.

- Tammaro, A. M. 2011. "Library and information science (LIS) education: A conceptual framework towards 'Europeisation"” Journal of the Bangladesh Association of Young Researchers 1(1): 1-13.

- Van Rij, V. 2015. “21st Century Higher Education: Quick Scan of Foresight and Forward Looks on Higher Education in the ICT Age: Discussion Paper". http://iite.unesco.org/files/news/639201/Foresight_on_HE_and_ICT_Discussion_paper.pdf.

- Vilar, Polona, Maja Žumer, Pisanski, Jan, Maja Krtalić, i EINFOSE teams 2018. Policy Recommendation for the Entry Requirements and Learning Outcomes Harmonization. http://einfose.ffos.hr/documents/ EINFOSE_IO5_Policy_Recommendations.pdf.

- Virkus, S. 2007. "Collaboration in LIS education in Europe: Challenges and opportunities" U Proceedings of the World Library and Information Congress: 73rd IFLA General Conference and Council - Libraries for the future: Progress, Development and Partnerships. Durban, South Africa. http://www.ifla. org/IV/ifla73/papers/134-Virkus-en.pdf. Datum pristupa: 6. 4. 2016.

- Virkus, S. 2008. "LIS education in Europe: Challenges and opportunities" U Informationskonzepte für die Zukunft: ODOK '07, uredio V. Neugebauer, 191-204. http://eprints.rclis.org/14978/1/odok07_ virkus.pdf. Datum pristupa: 2. 4. 2016.

- Virkus, S. 2015. Change and innovation in European Library and Information Science education. BiD: textos universitaris de biblioteconomia i documentació, 35. http://bid.ub.edu/en/35/virkus.htm. Datum pristupa: 2. 4. 2016. 


\title{
UNIVERSITY EDUCATION OF INFORMATION PROFESSIONALS: CHALLENGES AND POSSIBLE STEPS FORWARD
}

\begin{abstract}
Following changes in the field of the university education and a series of new tasks for modern information institutions this paper considers possible steps towards a systematic university education and continuous professional development of information professionals.

It is indisputable that it is possible to compare and find common characteristics of educational programs in the fields of information science, library science, library and information science, and programs offered by the so-called i-schools. In addition, there are a number of new providers of education programs in, for example, information economics, digital libraries, big data management, where content in librarianship (such as information organization, information retrieval, information behaviour, information literacy) can play a significantly more important role.

The aim of the paper is to highlight the trends in the European university area from the perspective of educating librarians and other information professionals, and to encourage educators to find optimal solutions within local circumstances (such as Bosnian and Herzegovinian). We intend to point out the need for systematic reflection and action that would respect traditionally understood competencies and critically look at new opportunities with the aim of designing attractive and sustainable university programs and programs that upgrade the acquired competencies with new ones.

These programs should be flexible enough to respond to the needs of new challenges such as managing a new University Library in Sarajevo.

Based on the experience of the recently completed Erasmus + EINFOSE project, we aim to single out key issues for future discussions and decisions.

Keywords: university education, information professionals, library science, information science, Erasmus + EINFOSE project
\end{abstract}

